\title{
Risk management: Systematization in the context of oil and gas projects
}

\author{
D.C Trinh
}

Postgraduate student, St. Petersburg Mining University, Saint Petersburg, Russia

A.E Cherepovitsyn

Doctor of Economic Sciences, Professor, St. Petersburg Mining University, Saint Petersburg, Russia

\author{
A.A Ilinova \\ Ph.D. of Economic Sciences, Associate professor, St. Petersburg Mining University, Saint Petersburg, \\ Russia
}

\begin{abstract}
A number of risks are known to exist in various stages of the projects i.e. from the initial stage through the planning and finally at the implementation stage. This may be related to either subjective or objective reasons. Risk management and systematization plays an integral role in the assessment of the feasibility of the projects and further to make decisive investments. Identification and systematization of risks require regular updates for operational management throughout the project life-cycle. This paper introduces the importance of systematizing the risks in projects for optimal project outcomes, during the search, exploration and development in oil and gas projects. The essence of the design, national and international spheres of oil and gas projects, as well as the relationship between them is presented. We further systematized the risks on the basis of the decomposition of risk factors by the sphere of their occurrence. The occurrence of most of the risks were found to be mostly associated with geology, oil and gas reserves, production factors, trades, markets, the economy, finances, investment environment, and political mechanism. It was deduced that the systematization of risks is one of the effective management-components and an optimum solution to achieving the desired outcomes with less to zero risks in oil and gas and oil projects.
\end{abstract}

Keywords: risk, systematization of risks, oil and gas projects, risk management

\section{INTRODUCTION}

The exploration and development stage in oil and gas projects is normally associated with a number of risks due to a number of factors. Firstly, this may be due to the complex nature of such projects at the stages of search, exploration, evaluation, development and operation, high capital intensity and long-pay back periods. A successful implementation of oil and gas projects requires complex technical, technological, organizational, economic and political decisions (ISO 31000:2009). In particular, such projects are characterized by uncertainties regarding the potential of reserves, production, components and the quality of oil and gas. In addition, the external factors of the business environment may also affect the projects such as: the national environment (the situation of macroeconomics, politics, law, culture, society); international environment (geopolitics, technological progress, development of renewable energy markets, the oil market and the price of oil) (IHRDC, 2017). These factors are closely related, therefore, the risks of oil and gas projects are intertwined, and when spread may 
affect the entire project or its part depending on the risk event, as well as on the ability to manage these risks.

Risk management plays a critical role in making investment decisions and effectively managing oil and gas projects. In particular, the systematization of risks is very important in ensuring a correct, complete and unified understanding of project risks and their subsequent management in the project. In this regard, it is necessary to compile a profile and a list of project risks, to assess the level of their impact; identify critical risks, find appropriate controls and solutions to minimize losses or increase benefits; develop risk management action plans (programs) for successful project implementation. The purpose of this study is to systematize the risks of oil and gas projects by their sphere of origin and to analyze key risk groups at such stages as establishing the context, identifying the risk and analyzing the risk from the point of view of its impact on the project goal.

\section{LITERATURE REVIEW}

In the scientific literature, the topic of systematization, analysis, assessment and management of project risks as a whole is well developed. Problems of identification and classification of risks in the process of project management were considered in various studies carried out by G.D. Antonov, O. Yu. Klein, A. Yu. Tsvetkova, E.M. Rogova, M.V. Tikhonov, Frederick Funston, Cooper D.F., Paul Hopkin, Robert Mark, Thomas S. Coleman, John Hollmann, etc.

Risk management (including systematization of risks) is one of the fundamental problems of business, especially in the context of integration into the global economy. In the oil and gas industry, risk management is becoming increasingly relevant, especially when taking into account risks such as politics, environmental safety, price fluctuations, society and technology. Ignoring risks can lead to closure of projects and bankruptcy of the company.

Business actions contain many risks, but also many opportunities to be firm and develop for those who understand them (Stephen Wagner, 2016). In other words, risk is an inevitable byproduct of all activities. Organizations and project teams cannot completely eliminate risks. The risk of an enterprise (project) is as a result of damages which arise from factors which are difficult to control. They affect the achievement of its goals (profit, market share, brand, corporate culture, social security, etc.). Risk management is a general decision that a corporate governance system must take to identify, prevent, or reduce losses when risks arise (Michel Crouhy \& Thomas S., 2017). And this becomes particularly relevant in project management, since the activities within the project are unique (not repetitive) (Polkovnikov, 2015).

Risks are associated with benefits. In business, high risk often brings great benefits (risk-return ratio). However, in some cases, high risk may lead not to benefits, but to losses, closure of the project, bankruptcy of the enterprise (Norman Marks \& David Vose, 2018). Systematization of risks in the process of project management not only protects assets, but also increases value and provides opportunities for business growth (John Hollmann, 2018).

Systematization of risks, accurate and comprehensive measurement and quantification of each risk based on continuous adjustment and reflection of these changes in management decisions are the most important tasks at all levels of management (Douglas et al. 2019).

This paper is therefore aimed at reviewing and analyzing both the international and Russian literature on the research topic and attempts to systematize the risks in oil and gas projects according to the scope of their occurrence. The basic methods used in the process of systematizing risks are considered, the basic principles of systematizing risks are identified. The decomposition of possible risks of oil and gas projects is presented; such more common risks as geological and operational are considered in more detail and their impact on the ultimate goal of the project is determined. 


\section{RESEARCH METHODS AND MATERIALS}

The study relied on the previous literature in the field of risk and project management to construct a theoretical basis. The main research method was desktop research, as well as general methods of scientific analysis (abstract-logical and comparative), methods of system analysis.

The decomposition method such as the risk management technique in the form of a process of establishing a context in: risk identification, risk analysis were also used directly to systematize and analyze risks. Information on practical activities in the field of risk management of Russian and foreign oil and gas companies was used as materials for the study. Much attention was paid to the analysis of the activities of the Vietnam Oil and Gas Group (PetroVietnam) in the field of risk management.

\section{RESULTS AND DISCUSSION}

As noted above, oil and gas projects are influenced by a number of factors that relates to the project (internal) environment itself, as well as to the external environment on a national and international scale. Figure 1 shows the role of the project management and systematization in national and international environments of the oil and gas projects, as well as the relationship between them.

Risk systematization is the process of identifying risk events from the internal and external operating environment that can affect the goals (tasks) of a project (Heriot Watt, 2017). Systematization of risks requires understanding and correctly identifying factors that can lead to risk events; that is, to determine the context, origin (source), causes (primary and secondary), as well as possible consequences. In the process of systematizing risks, the following questions arises (John Shortreed, 2016):

1. Which risks may appear in project management? To answer this question, it is necessary to systematically analyze the process or activity in order to identify possible risks at each stage.

2. Which forms and causes of risks could be? To answer this question, it is necessary to indicate the potential cause and situations or a description of the risks, incidents or accidents.

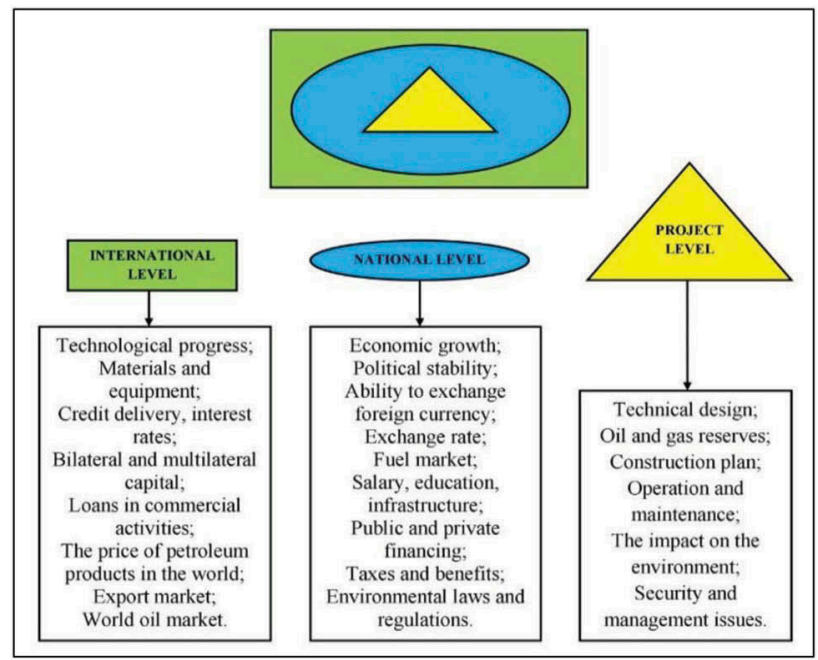

Figure 1. Levels of interconnection between operating environments of the oil and gas projects (Stephen Wagner et al. 2018). 
The risk systematization process will help to collect sufficient information and make a list of existing project risks. Various methods may be used in this process. The choice of specific methods depends on the complexity of the problem in consideration, the level of availability of information and resources. Some methods of risk management are presented in Table 1.

Effective methods of risk management are discussions, group work without limiting the participants, including the project team, business department, technical department, contractors, etc. (John Berhaz, 2015).

Oil and gas projects include a number of complex technical measures that are influenced by many factors from the project and business environment, therefore, the systematization of risks is not simple. Risk systematization should be carried out at the projects initiatial stage. Even if the project at the search and exploration stage has uncertainties, risks should be taken into account in the process of making investment decisions (Deloitte Vietnam Co., Ltd. 2018). This also form the basis for choosing risk response solutions during the project implementation. Systematization of risks should take into account the following factors to ensure the success of the process:

1. The need to establish goals (objectives) of the project. Risk is associated with the purpose of the project and affects its success. The interaction of risks and project objectives in project management are close (Vietnam Petroleum Institute (VPI), 2018).

2. The specificity of the risks in each project. There are differences at the project stage: search, exploration, evaluation, development and operation. Risks are temporary, and current risks may not be risks in the future (Nguyen Duc Huynh \& Le Thi Phuong, 2017).

3. The complexity and instability of risks in the systematization process. Not all risks are identified at the beginning; there are unknown risks that will appear in the future. Thus, risk systematization is a regularly updated process in the project life cycle (FMIT, 2018).

4. Risk systematization should be carried out by stakeholders and agreed in order to have a comprehensive view of risks (Klein, 2017).

5. In describing the risks need to be considered causal relationship. In order to correctly describe the risks, it is necessary to understand their relationship (Figure 2).

Table 1. Methods used in the risk systematization process (PVN-VPI, 2018).

\begin{tabular}{|c|c|c|c|}
\hline № & Methods & The purpose of the method & Description of the method \\
\hline 1 & $\begin{array}{l}\text { Questionnaire } \\
\text { (or interview) }\end{array}$ & $\begin{array}{l}\text { Identification of possible types of } \\
\text { risks. }\end{array}$ & $\begin{array}{l}\text { Preparation of a questionnaire on the types } \\
\text { of risks, the level of losses, the number of } \\
\text { cases of risk occurrence in a given period of } \\
\text { time. }\end{array}$ \\
\hline 2 & $\begin{array}{l}\text { Risk profile } \\
\text { check }\end{array}$ & $\begin{array}{l}\text { Identification of possible types of } \\
\text { risks. }\end{array}$ & $\begin{array}{l}\text { Consideration of the risk profile, which was } \\
\text { developed earlier. }\end{array}$ \\
\hline 3 & $\begin{array}{l}\text { Initiative } \\
\text { (brainstorming). }\end{array}$ & $\begin{array}{l}\text { Gather feedback (ideas) about the } \\
\text { risks. }\end{array}$ & $\begin{array}{l}\text { Instructions on how to share and discuss } \\
\text { ideas for summarizing a risk portfolio. }\end{array}$ \\
\hline 4 & Delphi Method & $\begin{array}{l}\text { Formation of expert consensus on } \\
\text { identified risks. }\end{array}$ & $\begin{array}{l}\text { Using the questionnaire to obtain opinions } \\
\text { and information from scientists and experts; } \\
\text { - Summary of results and transfer to other } \\
\text { experts for consensus. }\end{array}$ \\
\hline 5 & $\begin{array}{l}\text { Value chain } \\
\text { analysis }\end{array}$ & $\begin{array}{l}\text { Understanding the flow of events, } \\
\text { identifying significant risks at each } \\
\text { stage of the project. }\end{array}$ & $\begin{array}{l}\text { Development of a diagram, description of } \\
\text { work over time to determine the scope, } \\
\text { properties and operational characteristics of } \\
\text { the project. }\end{array}$ \\
\hline 6 & Change analysis & $\begin{array}{l}\text { The study about danger warnings, } \\
\text { the planned and inadvertent changes. }\end{array}$ & $\begin{array}{l}\text { Comparison of the current and previous } \\
\text { situation. }\end{array}$ \\
\hline 7 & $\begin{array}{l}\text { Research about } \\
\text { operability and } \\
\text { hazard }\end{array}$ & Identification of potential hazards. & $\begin{array}{l}\text { Separation of operational components; } \\
\text { study of the interaction between compo- } \\
\text { nents; systematic analysis of the relation- } \\
\text { ship between components; identification of } \\
\text { input data, properties, potential deviations; } \\
\text { record of the reason for deviations. }\end{array}$ \\
\hline
\end{tabular}




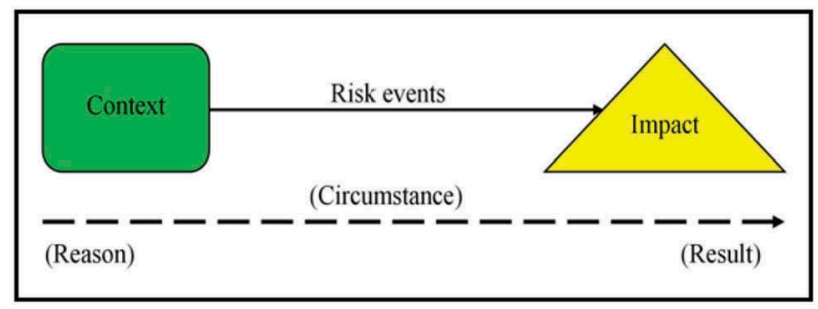

Figure 2. Description of risk (John Shortreed, 2016).

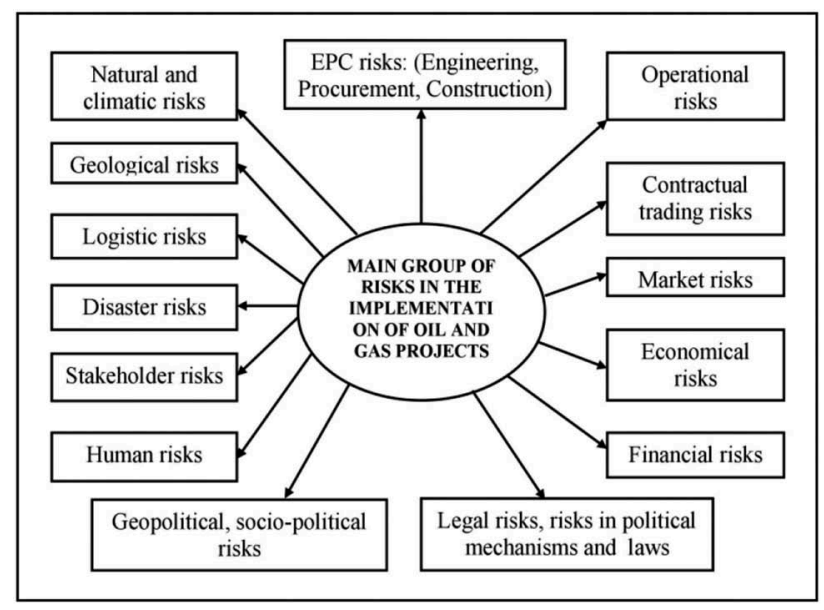

Figure 3. Decomposition of possible risks of oil and gas projects (Heriot Watt, 2017; ISO 31000:2009).

In the process of project implementation, various types of risks are manifested. The decomposition of possible risks of oil and gas projects is presented in Figure 3.

For risk analysis, it is necessary to understand the external and internal factors that can influence the success in achieving the objectives of the project (setting the context). Table 2 clearly shows the context for such risk groups as geological and operational, as well as the impact of these factors on the project goals.

\section{CONCLUSIONS}

Thus, based on our study, it can be concluded that oil and gas projects are subject to the influence of a whole range of risks, which were systematized according to such a sign as the scope of their occurrence.

Among the considered types of risks, geological risks are considered as typical, and are a determining factor for investments in exploration and production of oil and gas. Modern equipment and technologies, favorable financial conditions are really interesting only when the area in which it is planned to invest has oil potential. In general, depending on each phase of the project, type of project, the presented risk groups may appear in aggregate or separately, the level of their influence on the project also varies (Tsvetkova, 2016). For example, the risks of reserves and production volume decrease over the duration of the project. Consequently, for each project risks are dynamic, constantly changing, and their roster needs regular updating. 
Table 2. Analysis of geological and operational risks of the oil and gas projects (Phan Ngoc Trung \& Nguyen Thi Thanh Le, 2019).

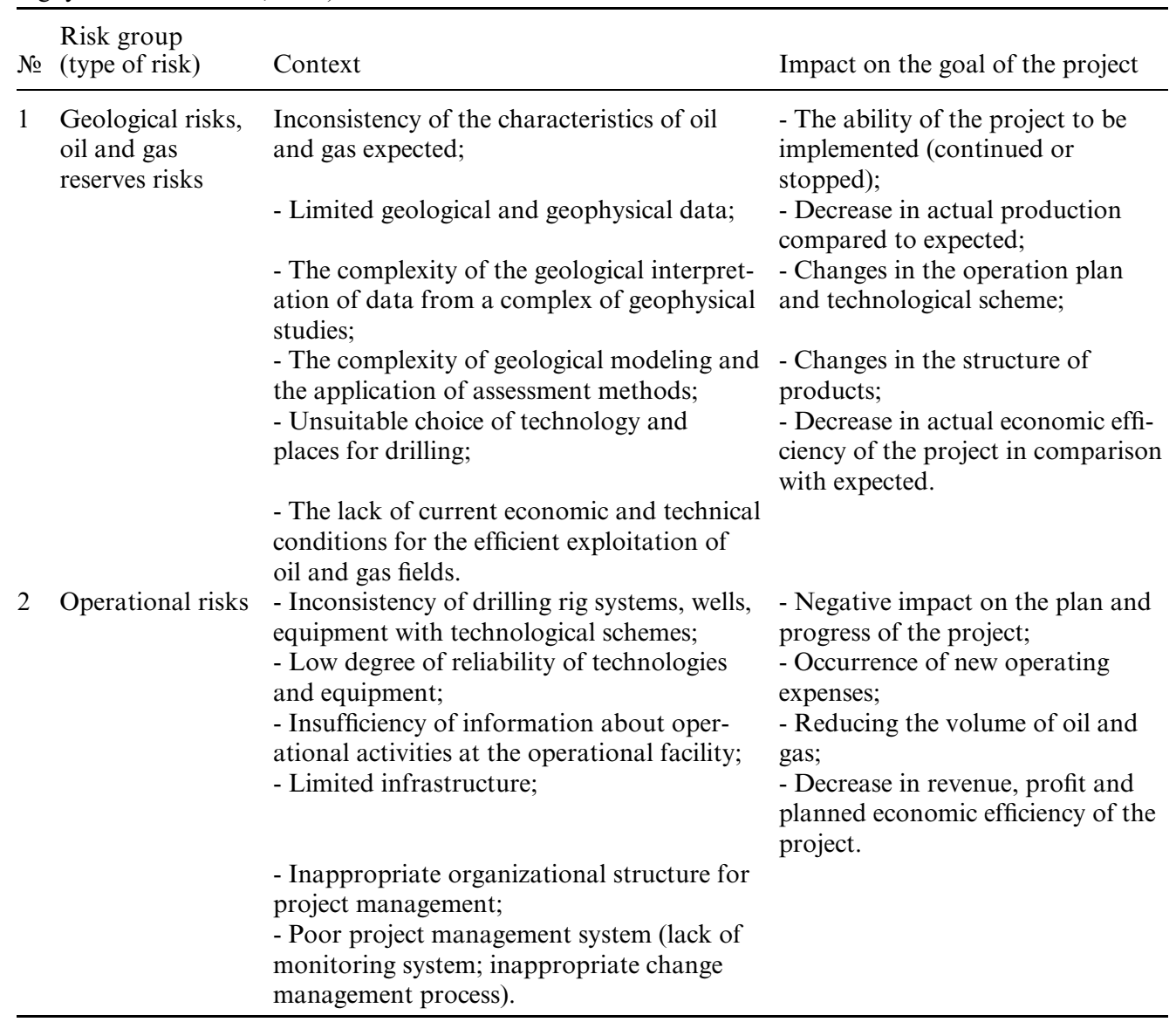

Oil and gas projects are subject to a sufficiently large number of risks in terms of geology, reserves, production, trade, markets, economics, finance, investment environment, politics, natural disasters, etc. Thus, the systematization of risks plays the role of a source of information to determine the characteristics of the project, development trends in the project management process and the selection of optimal solutions to achieve the project goals.

\section{ACKNOWLEDGEMENT}

The research was carried out with the financial support of the grant by the President of the Russian Federation for the state support of leading scientific schools of the Russian Federation, the number of the project NSh-2692.2020.5 "Modelling of ecological-balanced and economically sustainable development of hydrocarbon resources of the Arctic".

\section{REFERENCES}

Annual Report of Exxon Mobil, Total, BP, Repsol, 2018.

Antonov, G.D. 2019. Organization risk management: Textbook. Antonov, G.D. et al. - M .: Infra-M, - 464 p.

Balashov, A.I. 2016. Project Management: Textbook and workshop for academic undergraduate. Balashov, A.I. et al. - Lyubertsy: Yurayt, - 383p. 
Cooper, D.F. 2017. Project Risk Management Guidelines: Managing Risk in Large Projects and Complex Procuremen. Cooper, D.F. et al. John Wiley \& Sons, Ltd., England, 384 p.

Corporate Regulations on Enterprise Risk Management, 2019.

David Vose, 2018. Risk Analysis: A Quantitative Guide. John Wiley \& Sons, 3rd edition - 752

Deloitte Vietnam Co., Ltd. 2018. Survey report on enterprise risk management model for Vietnam Oil and Gas Group.

Douglas, W. Hubbard, 2019. Failure of Risk Management: Why It's Broken and How to Fix It. Wiley, 1 edition - 304 pages.

FMIT. 2018. Risk management and Internal control according to COSO standards.

Heriot Watt, 2017. Institute of Petroleum Engineering. Petroleum economics.

IHRDC, 2017. Petroleum project economics and risk analysis.

International Organization for Standardization. Risk management - Principles and guidelines. ISO 31000:2009.

John Berhaz, 2015. Business environment analysis and risk management in oil and gas industry. Probabilistic Publishing - $256 \mathrm{p}$.

John C. Hull, 2018. Risk Management and Financial Institutions. Wiley, 4th edition - 740 p.

John Hollmann, 2018. Project Risk Quantification. Probabilistic Publishing - 416 p.

John Shortreed, 2016. Basic frameworks for risk management. Network for Environmental Risk Assessment and Management. John Shortreed et al. John Wiley \& Sons - $180 \mathrm{p}$.

Klein O. Yu. 2017. Project risk insurance in the development of oil and gas fields. Notes of the Mining Institute, (S.1.), v. 155, n. 2, p. 201.

Michel Crouhy, 2019. The Essentials of Risk Management. Michel Crouhy et al. McGraw-Hill Education, 2 edition -672 p.

National Assembly of the Socialist Republic of Vietnam (Session XIII), 2014. Enterprise Law. No. 68/ $2014 / Q H 13$.

Nguyen Duc Huynh \& Le Thi Phuong, 2017. Identify risks of climate change affecting the activities of the oil and gas industry. McGraw-Hill Education. - Oil and gas magazine, № 8, p. 53-60.

Norman Marks, 2015. World-Class Risk Management. CreateSpace Independent Publishing Platform $234 \mathrm{p}$.

Paul Hopkin, 2018. Fundamentals of Risk Management: Understanding, evaluating and implementing effective risk. John Wiley \& Sons, Ltd., England. 480 Pages.

Phan Ngoc Trung \& Nguyen Thi Thanh Le, 2019. Overview of upstream oil and gas operations from the value chain approach. Oil and gas magazine, № 3, p. 63-69.

Polkovnikov, A.V. 2015. Project management. Full MBA course. Polkovnikov, A.V. et al. - M .: CJSC "Olympus Business" - 552 p.

Price water house Coopers (Vietnam) Co., Ltd. (PwC). Risk management training materials. 2018.

PVN-VPI. Building a risk assessment process for PVN's exploration and exploitation project. 2018.

Stephen Wagner, 2016. Surviving and thriving in uncertainty: creating the risk intelligent enterprise. Stephen Wagner et al. John Wiley \& Sons - 230 p.

Supervising State investment in enterprises; financial monitoring, performance evaluation and disclosure of financial information of state-owned enterprises and state-owned enterprises. Decree No. 87-2015ND-CP. 2015.

The Committee of Sponsoring Organizations of the Treadway Commission (COSO), 2017. Enterprise risk management framework.

The Institute of Internal Auditors, 2015. The three lines of defense in effective risk management and control.

Thomas S. 2017. Practical Guide to Risk Management. Thomas S. et al. Research Foundation of CFA Institute $-228 \mathrm{p}$.

Tsvetkova, A. Yu. 2016. Overview of the main risks of the enterprises of mining and metallurgical branches in modern conditions. Notes of the Mining Institute, (S.1.), v. 194, p. 339.

Vietnam Petroleum Institute (VPI), 2018. Study and propose a model of risk management organization for Vietnam Oil and Gas Group. 